\title{
AN EMPIRICAL ANALYSIS ON HOW CONSERVATISM INFLUENCES COST OF EQUITY CAPITAL: EVIDENCE FROM TURKEY*
}

\author{
Mehtap ÖNER ${ }^{* *}$ \\ Aslı AYBARS ${ }^{* * *}$ \\ Hüseyin EKIZZLER ${ }^{\star * * *}$
}

\begin{abstract}
An extensive review of literature focusing on theoretical and analytical studies reveals that equity markets will benefit from accounting conservatism due to the increase in overall information quality. Conditional conservatism, which is evaluated as to the asymmetry between the impact of good and bad news on earnings, is regarded to be a substitute of discretionary disclosure. Therefore, as the firms increase the extent of their voluntary disclosures, the cost of raising capital is alleviated since this cost depends on how much information is attained by the firms' potential investors. This study conducts a two stage analysis on a data set of nonfinancial firms listed on Borsa Istanbul 2005-2014, inclusive. Accordingly, the existence of conditional conservatism is tested by using cross-sectional regression based on the asymmetric timeliness model developed by Basu (1997) modified by Khan and Watts (2009). Consequently, the resulting firm-year measure of conditional conservatism is used as the explanatory variable of the panel data analysis. The originality of the paper stems from the fact that it attempts to provide evidence on the economic consequences of discretionary accounting practices from Turkey in this specific strand of literature related to the equity investors' required rates of return.
\end{abstract}

Keywords: Conditional Conservatism, Emerging Markets, Cost Of Equity Capital, Cross-Sectional Analysis, Panel Data Analysis

* Date of Submission: 10.08.2016; Date of Acceptance: 26.02.2017

** Marmara University, Faculty of Business Administration, Lecturer, Ph. D.

*** Marmara University, Faculty of Business Administration, Asst. Prof. Dr.

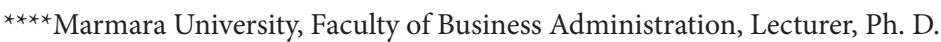




\section{İHTIYATLILIĞIN ÖZ SERMAYE MALIYYETİ ÜZERİNDEKİ ETKİSİ: TÜRKIYE ÖRNEĞİ}

\section{Öz}

Teorik ve analitik çalışmalara dayanan geniş bir literatür taraması sermaye piyasalarının, genel bilgi kalitesini arttıracağı gerekçesiyle muhasebedeki ihtiyatlılıktan fayda sağlayacağını ortaya koymuştur. İyi ve kötü haberlerin kazançlar üzerindeki asimetrik etkisi ile ölçülen koşula bağlı ihtiyatlılığın, isteğe bağlı açıklamaların yerine kullanılabildiği düşünülmektedir. Dolayısıyla, firmalar isteğe bağlı açıklamalarının miktarını arttırdıkça, sermaye bulma maliyetleri azalmaktadır; çünkü bu maliyet firmanın potansiyel yatırımcıları tarafından ne kadar bilgi edinildiğine bağlıdır. Bu çalışma, 20052014 yıllarını kapsayan bir gözlem süreci boyunca Borsa İstanbul'da yer alan reel sektör firmalarına ilişkin bir veri grubu üzerinde iki aşamalı bir analiz yapmaktadır. Bu doğrultuda, koşula bağlı ihtiyatlılığın varlığı kesitsel regresyon yöntemi kullanılarak Basu (1977) tarafından geliștirilen ve sonra Khan and Watts (2009) tarafından genişletilen kazancın asimetrik zamanlılı̆̆g modeli ile test edilmiştir. Buna bağlı olarak, bahsedilen regresyon analizi sonucunda ortaya çıkan firma-yıl bazındaki koşula bağlı ihtiyatlılık ölçüsü panel veri analizinde açıklayıcı değişken olarak kullanılmıştır. Çalışmanın özgünlüğü, hisse senedi yatırımcılarının talep ettiği getiriye ilişkin bu spesifik literatür başlığında, Türkiye'deki esnek muhasebe uygulamalarının ekonomik sonuçları ile ilgili kanıt sunmaya çalışmasından ileri gelmektedir.

Anahtar Kelimeler: Koşula Bağlı İhtiyatlılık, Gelişmekte Olan Piyasalar, Öz Sermaye Maliyeti, Kesit Analizi, Panel Veri Analizi

\section{INTRODUCTION}

Even though there is no single agreed upon definition for accounting conservatism, numerous definitions have been provided in literature dating back to the commonly agreed upon traditional expression of Bliss (1924) in that conservatism is defined as 'anticipate no profit, but anticipate all losses'. As emphasized by Watts (2003), anticipating profit means recognizing them before the existence of a verifiable legal claim to the revenues generating those profits. Thus, it is not implied by conservatism that cash flows should be received before the recognition of profits in that verifiability of those cash flows is the norm. In other words, stronger verifiability is required for the recognition of gains in comparison to losses with the degree of conservatism increasing as the asymmetry in verification of gains and losses increases. A consistent empirical definition is provided by Basu (1997) in the form of asymmetric timeliness of earnings with bad news being more quickly reflected than good news showing the need for higher degree of verification in the case of the recognition of goods news as gains than bad news as losses.

Previous studies have identified two general but distinct categories for conservatism as being either ex ante (unconditional) or ex post (conditional). While unconditional 
conservatism is news independent, accounting-based, and balance sheet related; conditional conservatism is news dependent, market based and earnings related (Chan et al., 2009). Beaver and Ryan (2005) state that unconditional conservatism relates to a systematic bias in book relative to market value, which is reflected in the understatement of the book value of net assets specifically due to unrecorded goodwill. Some examples can be stated as immediate expensing of RandD, use of accelerated depreciation and historical cost accounting. Contrarily, conditional conservatism emphasizes the situation; whereby, book values are written down under adverse circumstances but not written up under favorable conditions implying an asymmetry in terms of the earnings' response to good and bad news. Examples in this case can be stated as inventory valuation rules such the lower of cost or market and impairment accounting for tangible and intangible assets. Accordingly, whereas unconditional conservatism is more persistent and predictable by investors due to its being observable through accounting policy disclosures; conditional conservatism is less persistent and predictable to investors as they encompass a higher degree of managerial discretion.

Prominent studies in empirical literature start with the work of Basu (1997); whereby, conditional conservatism is evaluated as to the asymmetry between the impact of good and bad news on earnings. The measure developed by Basu (1997) is built on the notion that earnings more quickly reflect bad news than good news with the reasoning that a higher degree of verification is required for the recognition of good news. In other words, while book value of net assets is written down in a timely manner upon the receipt of sufficiently bad news, it is not written up that quickly upon the receipt of correspondingly good news resulting in conservative behavior (Ryan, 2006).

As emphasized by Ryan (2006), the seminal work of Basu (1997) is regarded to be one of the most influential studies in accounting arena. Even though the asymmetric timeliness model developed in this study is one of the mostly cited models in accounting literature, it encompasses certain drawbacks, which are summarized in the work of Ryan (2006). One of the limitations refers to the fact that all non-earnings information may not be reflected in returns and good and bad news may be reflected differently depending on the disclosure policy of the firm. Additionally, there may be a lag in the recognition of bad news due to issues associated with assessments of impairment and discretionary accounting behaviors. Furthermore, on the condition that information is aggregated over time, there may be problems associated with the measure's being an accurate proxy (Givoly et al., 2007). Dietrich et al. (2007) focuses on the econometric deficiencies of the model emphasizing the firm returns' being an endogenous variable; thus, not being a proper variable to be used as the independent variable of a reverse regression model proposed by Basu (1997). Nevertheless, this measure has certain strengths which are stressed by Wang et al. (2009). The asymmetric timeliness measure of conservatism is the mostly referred to and extensively utilized measure in empirical literature. Furthermore, the confidence of researchers in the measure has increased due to results of the studies being 
consistent with theoretical predictions. Another prominent strength to note is the adaptability of this measure to large samples in cross-sectional analysis.

The structure of the paper is arranged as follows: The following section focuses on a literature review with specific emphasis onto the results of the studies concentrating on our main variables of interest. The subsequent section is dedicated to hypothesis development. Empirical analysis part is revealed next with subsections concentrating on data and methodological issues. In the fifth section, the findings of the study are provided followed by concluding remarks.

\section{LITERATURE REVIEW}

This section is dedicated to the review of empirical studies that attempt to evaluate the link between conditional conservatism and cost of capital. As emphasized by Basu (1997), accounting practice and theory have been affected by conservatism for centuries. This study further attempts to delve into the topic by focusing onto its impact on financial practice with an emphasis on cost of capital, which is used as a crucial benchmark for identifying the ability of firms to make their potential investment decisions and evaluation of the success of their ongoing investments. Easley and O'Hara (2004) further stress the importance of cost of capital by focusing on its role in determining the mix of firms' capital structure. Thus, firms strive to reduce this ratio by developing numerous policies, one of which adheres to decisions regarding corporate disclosures.

Numerous studies have documented an inverse relationship with a higher degree of accounting conservatism leading to lower cost of equity capital. Artiach and Clarkson (2014) reveal that the strength of this relationship is conditional on the firm's information environment with a higher degree of information asymmetry leading to a greater reduction in cost of equity capital. The analysis, which is conducted on a data set of 3138 firm-year observations based on US-listed firms during the period between 1985 and 2000, reveals the decline in the marginal impact of conservatism on the selected proxy for cost of equity with conservatism being measured by the negative accruals measure of Givoly and Hayn (2000). Zare et al. (2013) also utilize the model of Givoly and Hayn (2000) for the measurement of conservatism on a dataset of 113 firms listed on Tehran Stock Exchange during the period between 2003 and 2009. The findings of the study demonstrate that cost of capital decreases as the degree of conservatism in the firm increases. Another concurrent study conducted by Khalifa and Othman (2015) utilizes the firm-specific measure of conditional conservatism developed by Khan and Watts (2009) based on Basu (1997) model to investigate the link between accounting conservatism and cost of equity capital. The results documented on a sample of 1896 firms from 13 countries in Middle East and North Africa region during the 2004-2007 period demonstrate a negative and significant relationship between the major variables of interest. Another study that utilizes 
a firm specific measure of conservatism based on Callen et al. (2010) is conducted by Lara et al. (2011) on a sample of US firms with 54,389 firm-year observations during the period between 1975 and 2003. The findings also show the existence of a negative relation between conditional conservatism and cost of equity capital. Li (2014) evaluates the issue from a different perspective in that country-level measure of conservatism based on Basu (1997) model is employed on a dataset made up of 349 country-year observations during the years between 1991 and 2007. A negative relationship is documented between conditional conservatism and cost of capital in countries with a stronger legal enforcement.

The relationship has also been evaluated with an emphasis on debt capital by the early work of Ahmed et al. (2002). They discuss that conservative accounting policies tighten dividend policy, which results in a reduction in the amount of return required by bondholders as the risk of excessive dividend payments is mitigated. The findings of the study based on both market-value-based and accrual based measures of conservatism reveal the presence of an inverse relationship between conservatism and cost of debt on a sample of firms driven from Compustat database during two periods; namely, 1993-1998 and 1987-1992.

Contradictory results have also been revealed in that some empirical studies document a positive association between conservatism and cost of equity capital. One of those studies belongs to Chan et al. (2009) providing evidence on a sample of 1,012 non-financial UK firms making up a total of 5,403 firm-year observations. The findings imply that different dimensions of conservatism demonstrate different effects of cost of equity capital. Whereas unconditional conservatism is evidenced to alleviate cost of equity capital, conditional conservatism is documented to lead higher cost of equity capital. Another study that investigates the influence of conditional conservatism on cost of equity capital utilizes a measure following Givoly and Hayn (2000) and Zhang (2008) to capture the degree of conditional conservatism on a dataset of US firms with 62,833 firm-year observations during the period from January 1986 and December 2008. A positive association between the major variables of interest is detected, however, the relationship is found to be less strongly experienced in the postSOX (post-Sarbanes Oxley Act) period due to alleviated information asymmetry, reduced fundamental business risk, and mitigated behavioral caused by SOX (Biddle et al., 2012).

Despite the presence of significant findings with either a positive or negative link between cost of capital and conditional conservatism, insignificant findings have been documented as well. One example can be documented as the study of Francis et al. (2004). This study investigates the relation between cost of equity and earnings quality by focusing on four accounting-based and three market-based attributes of earnings. The findings of the study reveal the greater impact of accounting based measures; namely, accrual quality, persistence, predictability, and smoothness on cost of equity in comparison to market-based attributes; namely, value relevance, timeliness, and conservatism. However, it has to be noted that the study fails to document any significant influence of conservatism proxy based on Basu (1997) on the major variable of interest. 


\section{HYPOTHESIS DEVELOPMENT}

The hypothesis generated in this study focuses on the array of literature that explores the impact of asymmetric reporting on the firms' cost of capital and associated market value (Guay and Verrrechia, 2007; Suijs, 2008; Beyer et al., 2010). In the seminal work of Guay and Verrecchia (2007), conservative accounting is interpreted as a financial reporting system; whereby, firms report low firm values whenever they arise, which is consistent with the empirical studies based on the asymmetric timeliness of earnings generated by Basu (1997). When low realizations are reported in a timely manner, full disclosure is achieved reducing the uncertainty about future cash flow expectations. As a result, cost of capital is reduced. This issue is further stressed in the study of LaFond and Watts (2008); whereby, they emphasize how conservatism mitigates managerial incentives for accounting manipulation resulting in reduced information asymmetry and higher firm value.

The significance of topic delving into the impact of disclosure policies on the firms' cost of capital has been highlighted by Beyer et al. (2010). Gietzmann and Trombetta (2003) claim accounting conservatism to be a substitute for voluntary disclosure. Hence, as the firms increase the extent of their voluntary disclosures, the cost of raising capital is alleviated since this cost depends on how much information is attained by the firms' potential investors. Easley and O'Hara (2004), state that disclosure is essential in turning private information to public information affecting asset prices. They further propose that firms with stocks having more private information and less public information are confronted with a higher cost of equity capital. They explain this relationship by the notion that stocks are less risky for informed traders resulting in those investors' holding more stocks. This, in turn, increases the demand for the stock, raising the price and reducing the cost of capital. Therefore, this mechanism turns out to be stronger as more information is disclosed about a stock. Furthermore, Givoly et al. (2007) state that the relationship between earnings and returns is affected by timing of information disclosures. It has to be noted that the cost of capital can be influenced by quality of accounting information both directly and indirectly. The direct affect arises due to the reduction in the covariance of a firm's cash flows with that of another on the condition that higher quality disclosure is achieved. On the other hand, the indirect effect arises from the improvement in the firm's real decisions due to the impact of higher quality disclosure (Lambert et al., 2007). Accordingly, the hypothesis regarding the relationship between cost of equity capital and conditional conservatism is structured as follows depending on the theoretical framework provided, literature review, and empirical evidence;

$\mathrm{H}_{1}=$ The higher the degree of conditional conservatism in the firm, the lower the firm's cost of equity capital. 


\section{EMPIRICAL ANALYSIS}

\section{IV.1. Dataset and Methodology}

This study covers the ten year observation period between the years 2005 and 2014, inclusive. The dataset utilized encompasses Bloomberg, Borsa Istanbul (BIST), and Public Disclosure Platform (KAP). A final number of 174 firms for each year making up a total of 1740 firm-year observations is included in order to achieve a balanced panel data model.

The methodology used in this study is mainly based on Basu (1997) despite the above stated criticisms directed towards the usage of this measure as a proxy for conservatism. As most of the prior studies have employed the Basu model, using a consistent measure is supposed to improve the comparability of our findings with those of the others. As stated by Givoly et al. (2007), returns act as an appropriate surrogate for news since prices reflect all publicly available information in a semi-strong form of market efficiency in a correct and timely manner.

Accordingly, the model generated by Basu (1997) that utilizes bad and good news as proxies for negative and positive stock returns, respectively, is constructed with a reverse regression model as follows;

$$
\mathrm{EAR}_{\text {it }}=\alpha_{0}+\alpha_{1} \mathrm{D}_{\text {it }}+\beta_{1} \mathrm{RT}_{\text {it }}+\beta_{2} \mathrm{D}_{\text {it }} * \mathrm{RT}_{\text {it }}+\epsilon_{\text {it }}
$$

where;

$\mathrm{EAR}_{\text {it }}=$ earnings; whereby earnings per share for firm $i$ in fiscal year $t$ is divided by price per share at the beginning of the fiscal year

$\mathrm{RT}_{i t}=$ return on firm $i$ from 9 months before fiscal year end $t$ to three months after fiscal year end $t$

$\mathrm{DR}_{\text {it }}=$ dummy variable equal to 1 if $\mathrm{R}_{\text {it }}<0$, equal to 0 otherwise

$\epsilon_{\text {it }}=$ error term in year $t$ for firm $i$

The timeliness measure for good news is denoted by $\beta_{1}$. It has to be noted that the asymmetry in the sensitivity of earnings to negative and positive returns is captured by $\beta_{2}$, which stands for the Basu asymmetric timeliness measure of conservatism. Thus, conservatism is supposed to be directly proportional to the values of $\beta_{2}$. Furthermore, total bad news timeliness is captured by $\beta_{1}+\beta_{2}$.

Based on the fact that the asymmetric timeliness model of Basu determines the degree of accounting conservatism in a global manner, we modify the model by depending on the prominent study of Khan and Watts (2009) to provide a firm-specific measure of conservatism, which is consistent with the structure of our dataset. The firm-specific characteristics 
that are integrated into the Basu model by Khan and Watts (2009) are size, market-to-book ratio, and leverage. Accordingly, $\beta_{1}$ and $\beta_{2}$ standing for timeliness of good news (G_Score) and incremental timeliness of bad news (C_Score); respectively, are constructed as the below linear functions of yearly firm-specific characteristics:

$$
\begin{aligned}
& \text { G_Score }=\beta_{1}=\mu_{0}+\mu_{1} S I Z E_{i}+\mu_{2} M T B_{i}+\mu_{3} L E V_{i} \\
& \text { C_Score }=\beta_{2}=\lambda_{0}+\lambda_{1} S I Z E_{i}+\lambda_{2} M T B_{i}+\lambda_{3} L E V_{i}
\end{aligned}
$$

where;

SIZE = natural log of total assets

$M T B=$ market value of equity divided by book value of equity

$L E V=$ total debt divided by market value of equity

It can be noted that $\mu_{i}$ and $\lambda_{i}(i=0, \ldots, 3)$ are constant across firms but vary over time as they are estimated from annual cross-sectional regressions based on Equations (2) and (3). These equations are substituted into Equation (1) above.

$\mathrm{EAR}_{i t}=\alpha_{0}+\alpha_{1} \mathrm{D}_{i}+R T_{i}\left(\mu_{0}+\mu_{1} S I Z E_{i}+\mu_{2} M T B_{i}+\mu_{3} L E V_{i}\right)+\mathrm{D}_{i} * R T_{i}\left(\lambda_{0}+\lambda_{1} S I Z E_{i}+\lambda_{2} M T B_{i}+\lambda_{3} L E V_{i}\right)+$ $\left(\delta_{1} S I Z E_{i}+\delta_{2} M T B_{i}+\delta_{3} L E V_{i}+\delta_{4} \mathrm{D}_{i} * S I Z E_{i}+\delta_{5} \mathrm{D}_{i} * M T B_{i}+\delta_{6} \mathrm{D}_{i} * L E V_{i}\right)+\epsilon_{i t}$

As an initial step, annual cross-sectional regressions are conducted by employing Basu (1997) model modified by Khan and Watts (2009) to capture the degree of conservatism. Finally, panel data analysis is conducted to evaluate the influence of accounting conservatism on the firms' cost of capital by the equation below:

$$
\operatorname{COC}_{\text {it }}=\beta_{0}+\beta_{1} C_{-} \text {Score }_{i t}+\beta_{2} L E V_{i t}+\beta_{3} S I Z E_{i t}+\beta_{4} M T B_{i t}+\epsilon_{i t}
$$

\section{IV.2. Proxies Utilized}

The dependent variable of the analysis is selected to be cost of equity capital as also employed in the studies of Chan et al. (2009), Lara et al. (2011), Li (2014), Artiach and Clarkson (2014). This variable is directly extracted from Bloomberg database. It has to be noted that the terms cost of capital and cost of equity capital are used interchangeably in this paper.

Conditional conservatism measure developed by Basu (1997) and modified by Khan and Watts (2009) is chosen to be the explanatory variable of the empirical model, which is provided in detail in the methodological part above.

The study controls for various risk factors that have a potential to influence the association between cost of equity capital and conditional conservatism. These variables are determined to be leverage, firm size, and market to book value. The leverage of the firm that is denoted by LEV is chosen to be the ratio of total debt to total assets. This control variable has also been included in the analysis of Ahmed et al. (2002), Chan et al. (2009), Zare et al. 
(2013), and $\mathrm{Li}$ (2014). Firm size, which is also employed as a control variable in numerous related studies (Chan et al., 2009; Artiach and Clarkson, 2014; Zare et al., 2013; Lara et al., 2011; Li, 2014; Ahmed et al., 2002). Our proxy is labeled by SIZE and captured by the natural logarithm of total assets. Lastly; market to book ratio, denoted by MTB, is incorporated as in the works of Lara et al. (2011) and Li (2014).

\section{EMPIRICAL FINDINGS}

This section focuses on the empirical findings of the study concentrating on the relationship between conditional conservatism and cost of equity capital. Firstly, the descriptive statistics as to the dependent, explanatory, control variables, and any other additional variables that are utilized in the prior cross sectional analysis are provided in Table 1, below. Outliers with respect to the variables labeled as COC, LEV, MTB, and C_Score are removed from the initial sample as the panel data analysis is being conducted.

Regarding the estimates of cost of equity capital, the mean and median values are $10 \%$ and $9.5 \%$, respectively, with a standard deviation of $2.7 \%$. An analysis of the quartiles reveals that whereas $25 \%$ of the sample has a cost of equity capital that is less than $8.2 \%, 75 \%$ has a cost of capital that is less than $12.1 \%$. Our conservatism measure denoted by C_Score has mean and median values of 0.653 and 0.178 , respectively. The 1 st and 3rd quartiles are found to be -0.160 and 0.604 , respectively. The mean value for the control variable that accounts for the degree of leverage is $50 \%$ with a high standard deviation of $45 \%$ demonstrating that the percentage of leverage varies across firms and time. Furthermore; the average firm size of 5.541 in logarithmic terms represents an asset size of 981 million in Turkish Liras with minimum and maximum values of 3.47 million and 31.88 billion Turkish Liras. The median value of MTB is found to be 1.308 with the 1st and 3rd quartiles being 0.811 and 2.156 , respectively.

Table 1. Descriptive Statistics

\begin{tabular}{|l|c|c|c|c|c|c|c|}
\hline & Mean & StdDev & Min & 1st Quartile & Median & 3rd Quartile & Max \\
\hline COC & 9.955 & 2.702 & -16.618 & 8.156 & 9.489 & 12.071 & 18.310 \\
C_Score & 0.653 & 5.092 & -70.531 & -0.160 & 0.178 & 0.604 & 99.194 \\
LEV & 0.501 & 0.455 & 0.006 & 0.265 & 0.447 & 0.649 & 8.674 \\
SIZE & 5.541 & 1.539 & 1.243 & 4.441 & 5.425 & 6.409 & 10.369 \\
MTB & 1.720 & 6.664 & -177.543 & 0.811 & 1.308 & 2.157 & 74.597 \\
\hline
\end{tabular}

Table 2 below demonstrates the Pearson Correlation Matrix between key variables. The findings reveal a positive link between conservatism and cost of capital though not significant. This relationship will be further evaluated in the panel data analysis. A significant and 
positive association is found between leverage and cost of capital. Firm size also demonstrates a positive and significant relation with cost of capital. No issue of multicollinearity is detected among the major variables of interest as seen by the below table.

Table 2. Pearson Correlation Matrix

\begin{tabular}{|l|c|c|c|c|c|}
\hline Variables & COC & C_Score & LEV & SIZE & MTB \\
\hline COC & 1.0000 & & & & \\
C_Score & 0.0373 & 1.0000 & & & \\
LEV & $0.0555^{*}$ & $0.2773 * *$ & 1.0000 & & \\
SIZE & $0.1138 * *$ & $-0.0550 *$ & -0.0164 & 1.0000 & \\
MTB & -0.0315 & $0.0613 * *$ & $-0.0522 *$ & -0.0089 & 1.0000 \\
\hline legend $* p<0.05 ; * * p<0.01$ \\
\hline
\end{tabular}

Table 3 below provides the findings as to the estimation of Equation 4 . The mean coefficients demonstrated are from annual cross-sectional (Fama-Macbeth) regressions of earnings variables listed on a total sample of 1,740 firm-year observations. The adjusted $\mathrm{R}^{2}$ is the average of the adjusted $\mathrm{R}^{2}$ from 10 annual regressions. The regressions are estimated annually and the mean coefficients are reported over the ten year total period. C_Score is calculated for each firm-year as in Equation 3 above.

Accordingly, the findings of Equation 5 are reported on Table 4 below. The coefficient of the variable labeled as C_Score; which measures conditional (ex post) conservatism, is negative but insignificant. Even though, the direction of the relationship is as expected, no significant result has been documented for our dataset during the observation period. As emphasized in the sections devoted to literature review and hypothesis development, majority of prior studies have demonstrated a negative and statistically significant association between these main variables of interest. 
Table 3. Mean Coefficients from Estimation Regressions (Dependent Variable is EAR)

\begin{tabular}{|l|c|c|}
\hline Independent variable & Coefficient & t-stat. \\
\hline Intercept & -0.149 & -.676 \\
D & 0.115 & .394 \\
Ret & -0.066 & .254 \\
RetxSize & 0.113 & 1.017 \\
RetxMB & 0.215 & -.545 \\
RetxLev & -1.994 & -1.768 \\
& & \\
DxRet & 0.369 & .208 \\
DxRetxSize & -0.056 & -.291 \\
DxRetxMB & -0.300 & .101 \\
DxRetxLev & 1.923 & .557 \\
& & \\
Size & 0.013 & .868 \\
MB & -0.028 & -.171 \\
Lev & 0.400 & .914 \\
DxSize & 0.029 & .196 \\
DxMB & 0.059 & .957 \\
DxLev & -0.785 & -1.689 \\
\hline Adjusted R2 & 0.349 & \\
\hline
\end{tabular}

All of the results with respect to the control variables are found to be statistically significant. Firm leverage is found to demonstrate a positive link with cost of equity capital ( $\mathrm{z}$-value $=4.55, \mathrm{p}<0.01)$. This result is in line with the study of Ahmed et al. (2002), Chan et al. (2009), and $\mathrm{Li}$ (2014). The positive influence of firm size on the main variable of interest ( $\mathrm{z}$-value $=$ $5.75, \mathrm{p}<0.01)$ is also supported by the study of Ahmed et al. (2002). Lastly, market to book ratio also inserts a negative influence on cost of equity capital $(\mathrm{z}$-value $=-5.75, \mathrm{p}<0.01)$ with the result being supported by Li (2014). 
Table 4. Findings as to The Relationship between COC and C_SCORE

\begin{tabular}{|l|c|c|c|}
\hline \multicolumn{4}{|c|}{ Dependent Variable : COC } \\
\hline Variables & $\begin{array}{c}\text { Coefficient } \\
\text { estimates }\end{array}$ & $\begin{array}{c}\text { Standard } \\
\text { errors }\end{array}$ & z-statistics \\
\hline C_Score & -0.0075 & 0.0147 & -0.51 \\
LEV & 1.1720 & 0.2577 & $4.55 * * *$ \\
SIZE & 0.2631 & 0.0457 & $5.75^{* * *}$ \\
MTB & -0.1259 & 0.0219 & $-5.75^{* * *}$ \\
constant & 8.1388 & 0.2931 & $27.76^{* * *}$ \\
\hline Number of observations & 1711 \\
Number of groups & 173 & \\
Wald chi2(4) & 88.68 \\
Prob $>$ chi2 & 0.0000 \\
\hline legend $* p<0.10 ;$ & $* * p<0.05 ;$ & $* * * p<0.01 ;$ \\
\hline
\end{tabular}

\section{CONCLUDING REMARKS}

This study focuses on conservative accounting practices by evaluating the influence of conditional conservatism on cost of equity capital. Based on previous empirical and theoretical studies, a negative association is hypothesized; whereby, the proxy that accounts for conditional conservatism is considered to alleviate the measure of cost of capital.

The dataset specifically focuses on an emerging market economy with 1740 firm-year observations belonging to BIST during the ten year period between 2005 and 2014. A two stage analysis is applied with conditional conservatism being measured by the model developed by Basu (1997) modified by Khan and Watts (2009) with the utilization of cross-sectional yearly regressions. Consequently, the captured conservatism measure is used as the explanatory variable of the panel data analysis that uses cost of capital as the dependent variable.

The expected direction of the relationship that is hypothesized to be negative has been captured in this study though with insignificant results after controlling for firm leverage, size, and market to book ratio. An evaluation of the prior studies reveals the fact that there is lack of consistent findings on the specified relationship. Some have documented significant and negative results; whereas others have documented significant yet positive results. Examples of insignificant findings can be demonstrated as well. This may arise due to the existence of numerous measures that act as proxies for the major variables of interest; namely, conservatism and cost of capital. Accordingly, further studies can be conducted with different proxies of conservatism and cost of capital and the proposed relationship can be retested in BIST to reveal whether the link is sensitive to alternative measures for the major variables of interest. 


\section{References}

Ahmed, S., Billings, B. K., Morton, R. M. and Stanford-Harris, M. (2002). The Role of Accounting Conservatism in Mitigating Bondholder-Shareholder Conflicts over Dividend Policy and in Reducing Debt Costs. The Accounting Review, 77.4, 867-890.

Artiach, T. C. and Clarkson, P. M. (2014).Conservatism, Disclosure and the Cost of Equity Capital. Australian Journal of Business, 39.2, 293-314.

Basu, S. (1997). The Conservatism Principle and the Asymmetric Timeliness of Earnings. Journal of Accounting and Economics, 24, 3-37.

Beyer, A., Cohen, D. A., Lys, T. Z. and Walther, B. R. (2010). The Financial Reporting Environment: Review of the Recent Literature. Journal of Accounting and Economics, 50, 296-343.

Biddle, G. C., Ma, M. L. Z. and Wu, F. (2012). Conditional Conservatism and the Cost of Equity Equity Capital: Informational, Fundamental, and Behavioral Effects, Working Paper, SSRN Electronic Journal, 04/2012; DOI: 10.2139/ssrn.1985800

Bliss, J.H. (1924). Management through Accounts. New York, NY: The Ronald Press Co.

Chan, A. L. C., Lin, S. W. J. and Strong, N. (2009). Accounting Conservatism and the Cost of Equity Capital: UK Evidence, Managerial Finance, 33.4, 325-345.

Dietrich, J., R., Muller III, K. A. and Riedl, E. J. (2007). Asymmetric Timeliness Tests of Accounting Conservatism. Review of Accounting Studies, 12, 95-124.

Easley, D. and O'hara, M. (2004). Information and the Cost of Capital. The Journal of Finance, 59.4, 1553-1583.

Francis, J., LaFond, R., Olsson, P. M. and Schipper, K. (2004). Cost of Equity and Earnings Attributes. The Accounting Review, 79.4, 967-1010.

Gietzmann, M., B. and Trombetta, M. (2003). Disclosure Interactions: Accounting Policy Choice and Voluntary Disclosure Effects on the Cost of Raising Outside Capital. Accounting and Business Research, 33.3, 187-205.

Givoly, D. and Hayn, C. (2000). The Changing Time-series Properties of Earnings, Cash Flows and Accruals: Has Financial Reporting Become More Conservative. Journal of Accounting and Economics, 29.3, 287-320.

Givoly, D., Hayn, C. K. and Natarajan, A. (2007). Measuring Reporting Conservatism. The Accounting Review, 82.1, 65-106.

Guay, W. and Verrecchia, R. E. (2007) . Conservative Disclosure, Working Paper, available at SSRN:http://ssrn.com/abstract=995562 or http://dx.doi.org/10.2139/ssrn.995562

Khalifa, M. and Othman, H.B. (2015). The Effect of Conservatism on Cost of Capital: MENA Evidence. Applied Economics, 47.1, 71-87.

Khan, M. and Watts, R. L. (2009). Estimation and Empirical Properties of a Firm-year Measure of Accounting Conservatism. Journal of Accounting and Economics, 48, 132-150. 
LaFond, R. and Watts, R. L. (2008). The Information Role of Conservatism. The Accounting Review, 83.2, 447-478.

Lambert, R., Leuz, C. and Verrecchia, R. E. (2007). Accounting Information, Disclosure, and the Cost of Capital. Journal of Accounting Research, 45.2, 385-420.

Lara, J. M. G, Osma, B. G. and P, F. (2011). Conditional Conservatism and Cost of Capital. Review of Accounting Studies, 16, 247-271.

Li, X. (2014). Accounting Conditional Conservatism and the Cost of Capital: An International Analysis, Available at SSRN: http://ssrn.com/abstract=1261971 or http://dx.doi. org/10.2139/ssrn.1261971.

Ryan, S. G. (2006). Identifying Conditional Conservatism. European Accounting Review, 15.4, 511-525.

Suijs, J. (2008). On the Value Relevance of Asymmetric Financial Reporting Policies. Journal of Accounting Research, 46.5, 1297-1321.

Wang, R. Z., Hogartaigh, C. O. and Zijl, T. V. (2009). Measures of Accounting Conservatism: A Construct Validity Perspective. Journal of Accounting Literature, 28, 165-203.

Watts, R. L. (2003). Conservatism in Accounting Part I: Explanations and Implications. Accounting Horizons. 17.3, 207-221.

Beaver, W. H. and Ryan, S. G. (2005). Conditional and Unconditional Conservatism: Concepts and Modeling. Review of Accounting Studies, 10, 269-309.

Zare, R., Heidari, Z., Salehi, M. and Jourkesh, H. (2013). Disclosure, Conservatism and their Influence on Cost of Capital of the Companies Accepted by Tehran Stock Exchange (TSE). Research Journal of Applied Sciences, Engineering and Technology, 5.22, 5188-5193.

Zhang, J. (2008). The Contracting Benefits of Accounting Conservatism to Lenders and Borrowers, Journal of Accounting and Economics, 45.1, 27-54. 


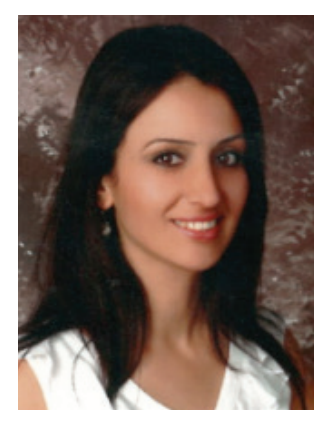

Mehtap ÖNER - mehtap.oner@marmara.edu.tr

She is a Ph.D. at Marmara University, Faculty of Business Administration. She accomplished her Ph.D. degree in Accounting and Finance at Marmara University Institute of Social Sciences in 2013. She pursues her research in the area of corporate finance

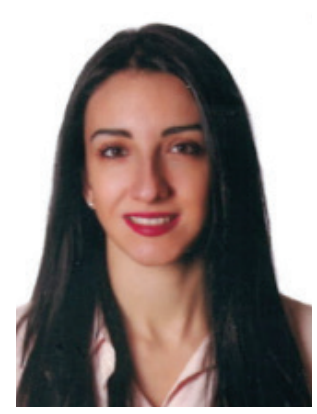

Aslı AYBARS - asli.aybars@marmara.edu.tr

She is an Assistant Professor at Marmara University, Faculty of Business Administration. She accomplished her Ph.D. degree in Accounting and Finance at Marmara University Institute of Social Sciences in 2013. She pursues her research in the area of corporate finance.

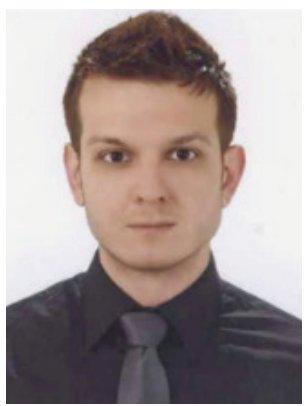

Hüseyin EKİZLER - hekizler@marmara.edu.tr

Received bachelor degree from İstanbul University, Department of Industrial Engineering, his first master's degree from İstanbul University, Institute of Graduate Sciences and Engineering in the same department and his second master's degree in Quantitative Methods (in English) from Marmara University, Institute of Social Sciences. He received $\mathrm{Ph} . \mathrm{D}$ degree in Quantitative Methods from the İstanbul University, Institute of Social Sciences. He is currently working as a lecturer in Marmara University, Faculty of Business Administration, Department of Business Administration (in English). He teaches courses on statistics, operations research and simulation theory at the undergraduate level. $\mathrm{He}$ pursues his research in the area of decision sciences. 
